\title{
Performance Research on Floating and Ground Mounted PV System
}

\author{
P.U. Poornima, R. Brindha, K. Subha Sharmini, Mallidi Goutham Reddy, P.Pavani, \\ Makkena Sri Hari
}

\begin{abstract}
The limited fossil fuels and demand for the energy made renewable a booming source of generating energy. An enormous amount of solar energy made it a best alternative renewable energy, which is free of cost and unlimited source of energy, eco-friendly and sustainable to the environment. But during the execution of panels on land has the burden of intense land requirements which is a premium commodity. The hurdles faced are land availability, land acquisition, land development and, land evacuation. Earth is covered with $70 \%$ of water. So, most of the solar energy is captured by water compared to land. To conserve the valuable land and water, installing a solar PV system on water bodies like oceans, lakes, lagoons, reservoirs, canals and water storage tanks are an appropriate option. They have numerous advantages compared to land installed solar panels. They reduce the valuable land area, reduce evaporation of drinking water, cooling of solar panels by the water below the panels. Additionally, the aquatic environmental profits by the solar installation limit the algae growth and potentially improves water quality. In this paper a new method of the float was discussed, a comparison is made between the floating PV system and standalone PV system. This method also improves the efficiency of the solar panel. A Small prototype has been designed and the results were plotted for different loads.
\end{abstract}

Keywords Renewable energy, floating PV system, solar irradiation, cell temperature, efficiency, high-density polyethylene

\section{INTRODUCTION}

With the rapid growth of population, the energy demand has been increasing exponentially for human needs. The demand should be met without affecting the environment. The consequences of environmental pollution let the world shift towards renewable energy [1]. For the development of renewable energy, the ISA summit was conducted with the help of UNCCC (United Nations Climate Change Conference) in 2016. The main objective of the summit is to work for efficient exploitation of solar energy to reduce dependence on fossil fuels. So, India had participated in the

summit and the government of India has been decided to generate the energy of $100 \mathrm{GW}$ using solar energy from 20
MW which was planned before [2]. Under the JNNSM (Jawaharlal Nehru National Solar Mission) of India, the target can't be reached using standalone, rooftop, and other application PV systems.

The floating solar PV plants are the advantage to generate energy from solar PV systems [3]. floating solar panels are placed to cover the surface of the irrigation canals, reservoirs, lakes, summer storage tanks of cities, quarries and few ponds. By placing the solar panels over the water increases the efficiency and life span of the solar panel. Commercial PV modules which are available in the market can generate 6-18 $\%$ of electrical energy [4]. The generation capacity of the solar panel increases by $16 \%$ due to cooling [5]. The maximum efficiency of solar cell can be obtained with ideal values such as operating temperature and solar irradiation [6].

If the operating temperature of the solar cell increases by $1^{0} \mathrm{C}$ the efficiency of the cell will decrease by $0.485 \%$ [7]. Abdolzadeh and Ameri proposed the new methodology of cooling and maintaining the ambient temperature of Photovoltaic cell using water sprinklers [8]. This laid the foundation for a different cooling process like using a thin metallic sheet in the middle or fins at the back wall of air duct which transfers heat in augmentations in an air-cooled thermal solar collector to increase its efficiency [9]. Anderson has proposed two methods which will increase both the thermal and electrical efficiency. Firstly, maximizing the ratio of the cooling tube width to spacing. Secondly, by implementing thermal conductive adhesives provides good thermal contact between the photovoltaic module and the absorber will be achieved [10].

This paper consists of three sections. Section 1 consists of design of PV cell with ideal characteristics and practical values and the efficiency of the panel on no load is calculated. Section 2 comprises of a new method of float designed for floating the solar panel. The output and efficiency comparison of floating solar panel and ground mounted panel has been categorized under section 3 .

Revised Version Manuscript Received on 10, September 2019.

P.U. Poornima, Department of EEE, SRM IST, Chennai, Tamil Nadu, India.(Email: poornimakandati@gmail.com)

R. Brindha, Department of EEE, SRM IST, Chennai, Tamil Nadu, India.(Email: brinda.r@ktr.srmuniv.ac.in)

K. Subha Sharmini, Department of EEE, SRM IST, Chennai, Tamil Nadu, India.(Email: subha.k@ktr.srmuniv.ac.in)

Mallidi Goutham Reddy, Department of EEE, SRM IST, Chennai, Tamil Nadu, India.(Email: gouthamreddy_ve@ srmuniv.edu.in )

P.Pavani, Department of EEE, SRM IST, Chennai, Tamil Nadu, India.(Email: prathapanenipavani@gmail.com)

Makkena Sri Hari, Department of EEE, SRM IST, Chennai, Tamil Nadu, India.(Email: sriharimakkena04@gmail.com) 


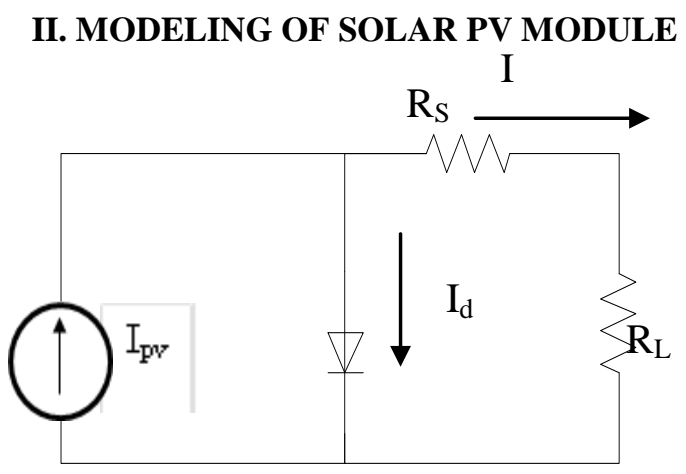

Fig1. Equivalent circuit of a solar cell

Figure 1 shows the equivalent circuit of a solar cell. The modelling of the panel is done using the equivalent circuit.

Using superposition principle, the output current is expressed as

$$
\begin{gathered}
\mathrm{I}=\mathrm{I}_{\mathrm{pv}}-\mathrm{I}_{\mathrm{d}}---- \\
\mathrm{I}_{\mathrm{pv}}=\left[\mathrm{I}_{\mathrm{sc}}+\mathrm{K}_{1}\left(\mathrm{~T}_{\mathrm{c}}-\mathrm{T}_{\mathrm{r}}\right)\right] \mathrm{G}
\end{gathered}
$$

Where, $\mathrm{I}_{\mathrm{sc}}$ is the short circuit current of the cell,

$\mathrm{K}_{1}$ is the short circuit current temperature coefficient of the cell,

$\mathrm{T}_{\mathrm{c}}$ and $\mathrm{T}$ are the working temperatures of cell and reference temperature respectively in ${ }^{\circ} \mathrm{C}$.

Using Shockley Equation, $\mathrm{I}_{\mathrm{d}}$ can be expressed as

$$
\mathrm{I}_{\mathrm{d}}=\mathrm{I}_{\mathrm{s}}\left\{\exp \left[\frac{q\left(V+I R_{S}\right)}{A k T_{C}}\right]-1\right\}
$$

Where, $I_{s}$ is the diode saturation current

$\mathrm{q}$ is the electron charge

$\mathrm{V}$ is the output voltage of the PV cell

I is the output current of PV cell

$\mathrm{A}$ is the diode ideality constant

$\mathrm{K}$ is the Boltzmann constant

The diode saturation current is given by

$$
\mathrm{I}_{\mathrm{s}}=\mathrm{I}_{\mathrm{rs}}\left(\frac{T_{c}}{T_{r}}\right)^{3} \exp \left[\frac{q E_{g}}{A k}\left(\frac{1}{T_{c}}-\frac{1}{T_{r}}\right)\right]
$$

Where,

$\mathrm{I}_{\mathrm{rs}}$ is the diode reverse saturation current

$E_{g}$ is the band gap energy of the semiconductor used in the cell

The diode reverse saturation current is given by

$$
\mathrm{I}_{\mathrm{rs}}=\frac{I_{S c}}{\exp \left(\frac{q V_{o c}}{A k T_{c}}\right)-1}
$$

Where, $\mathrm{V}_{\mathrm{oc}}$ is the open circuit voltage

$I_{s c}$ is the short circuit current

The output current is obtained by substituting the above equations in equation 1

$$
\mathrm{I}=\mathrm{I}_{\mathrm{pv}}-\mathrm{I}_{\mathrm{s}}\left\{\exp \left(\frac{q\left(V+I R_{S}\right)}{A k T_{c}}\right)-1\right\}
$$

\section{DESIGN OF SOLAR PV PANEL}

\begin{tabular}{|l|l|}
\hline Maximum power & $60 \mathrm{~W}$ \\
\hline Voltage at $\mathrm{P}_{\max }$ & $17.1 \mathrm{~V}$ \\
\hline Current at $\mathrm{P}_{\max }$ & $3.5 \mathrm{~A}$ \\
\hline Minimum power $\mathrm{P}_{\min }$ & $58 \mathrm{~W}$ \\
\hline Short circuit current $\mathrm{I}_{\mathrm{sc}}$ & $3.8 \mathrm{~A}$ \\
\hline Open circuit voltage $\mathrm{V}_{\mathrm{oc}}$ & $21.1 \mathrm{~V}$ \\
\hline
\end{tabular}

Table. I. 60watt solar panel specifications
The specifications shown in table I are considered for the designing of solar module. The modelling is done in matlab as shown in figure 2 and 3 . The modelling is done using the equations 1 to 6 . The characteristics at different irradiances and temperatures are shown in figure 4,5 and $6.635 \mathrm{~W} / \mathrm{m}^{2}$ is the irradiance at the location at which the experiment is conducted and is found by calculation in the later section.

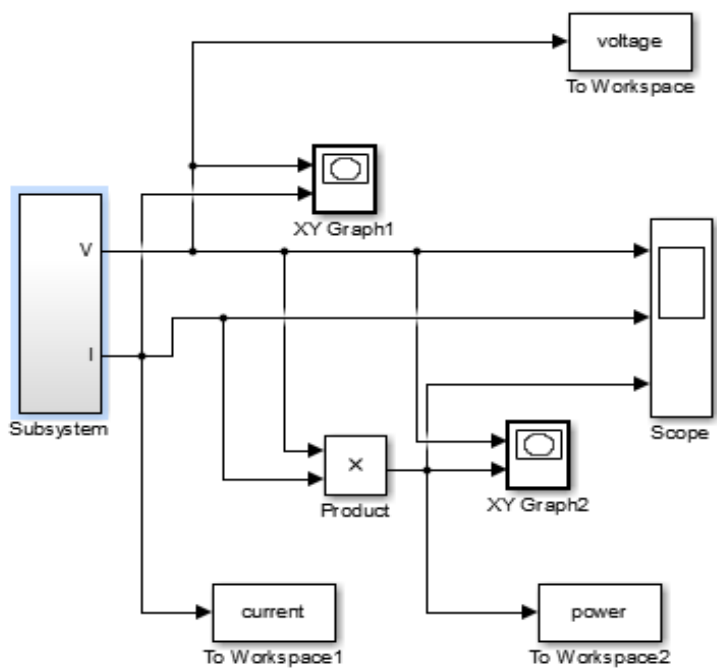

Fig 2. Simulation of solar PV panel

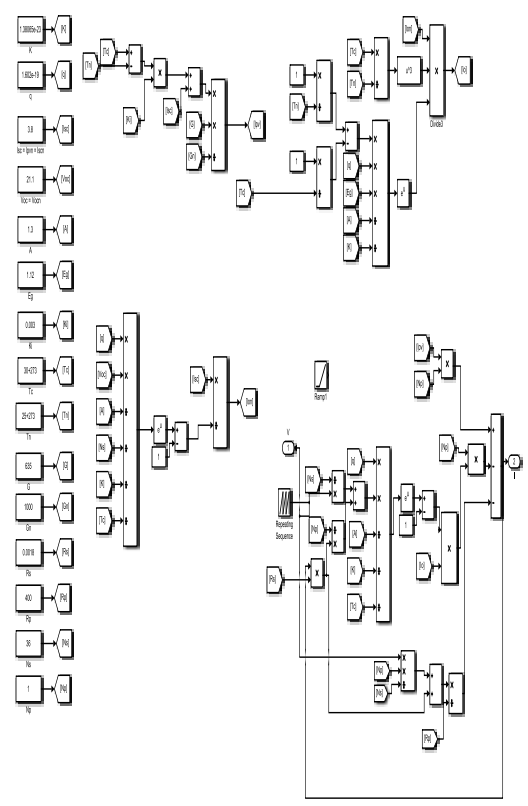

Fig 3. Design of solar PV module 


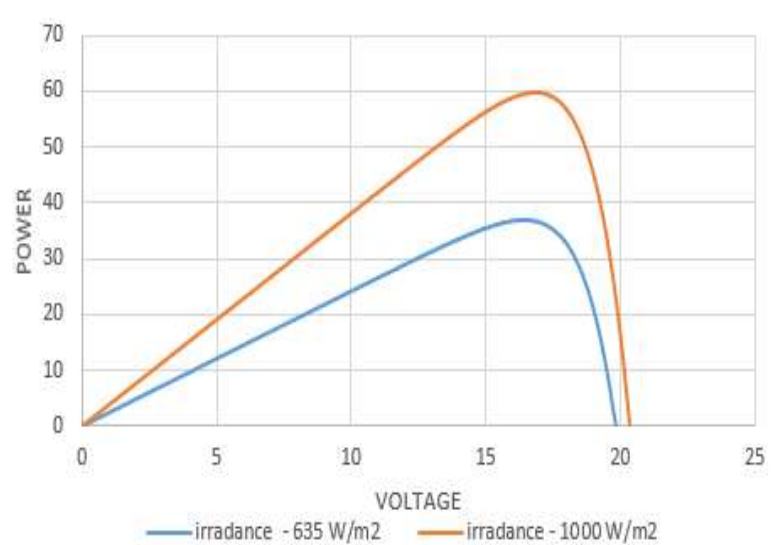

Fig 4. PV characteristics at different solar irradiance

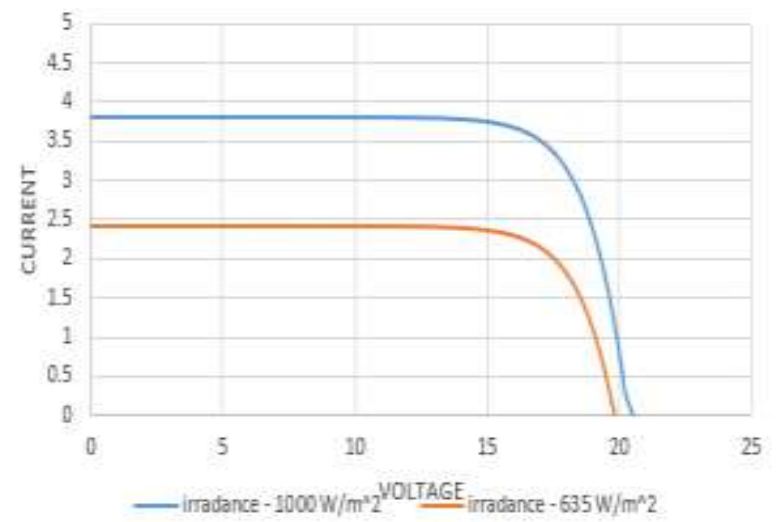

Fig 5. IV characteristics at different solar irradiance

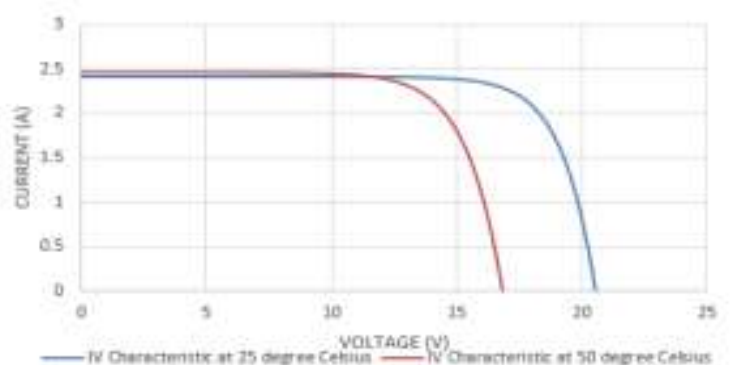

Fig 6. IV characteristics at different cell temperatures

\section{CALCULATIONS}

Maximum ideal power of solar panel as on Matlab $=59 \mathrm{~W}$

Total power output $=$ number of panel*power output

$$
=1 * 59=59 \mathrm{~W}
$$
day)

Total generation in year $=$ Power Output $* 2920 \quad(8 \mathrm{hrs}$ a

$$
=59 * 2920=172280 \mathrm{~W}
$$

Total average mean Potheri's solar radiation from figure 7 is $5.08 \mathrm{KWh} / \mathrm{m}^{2}$

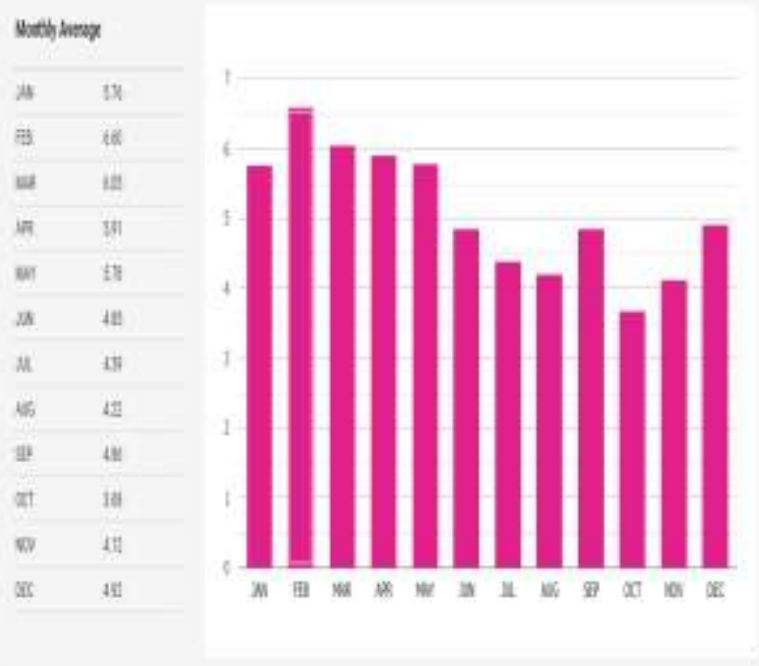

Fig 7. Monthly average irradiation of Chennai

Yearly Global Radiation $=$ Mean Radiation $* 365=5.08 *$ $365=1854.2 \mathrm{KWh} / \mathrm{m}^{2}$

Average yearly irradiation $=\frac{\text { Yearly } \text { irradiation }}{\text { Number of Hours }}=\frac{1854,2}{2920}=$ $635 \mathrm{~W} / \mathrm{m}^{2}$

Average yearly irradiation at $12.8183^{\circ} \mathrm{N}$ latitude and $80.0384^{\circ} \mathrm{E}$ longitude of India is found out to be $635 \mathrm{~W} / \mathrm{m}^{2}$. The ideal irradiation is $1000 \mathrm{~W} / \mathrm{m}^{2}$. Hence the efficiency of the panel decreases. This floating PV system curbs the effect of solar irradiation and the increase the efficiency of solar panel to a certain extent.

\section{FLOATING PANEL STRUCTURE}

The pontoon is the floating structure which provides enough buoyancy and support to solar panel. Different systems can be used to design the floating structure. Some systems have the pontoon as the mechanical structure which has a disadvantage during over flooding. This has been overcome by using electrical machinery to support the structure. Cost and energy for machinery had become the issue. To overcome these limitations different materials are considered such as rubber, aerogel, polyethylene, HighDensity Poly Ethylene (HDPE),

etc. the properties of the different materials are shown in the table1.

Table. II. Properties of different material

\begin{tabular}{|l|l|l|l|}
\hline Property & HDPE & Rubber & Aerogel \\
\hline $\begin{array}{l}\text { Strength to } \\
\text { density ratio }\end{array}$ & $930-970 \mathrm{Kg} / \mathrm{m}^{3}$ & $\begin{array}{l}15-20 \\
\mathrm{Kg} / \mathrm{m}^{3}\end{array}$ & $\begin{array}{l}300-1000 \\
\mathrm{Kg} / \mathrm{m}^{3}\end{array}$ \\
\hline $\begin{array}{l}\text { Withstand } \\
\text { temperature }\end{array}$ & $\mathrm{Up}$ to $120^{\circ} \mathrm{C}$ & $\begin{array}{l}\mathrm{Up} \\
300^{0} \mathrm{C}\end{array}$ & $\begin{array}{l}\mathrm{Up} \text { to } 350^{0} \\
\mathrm{C}\end{array}$ \\
\hline $\begin{array}{l}\text { Cost per } \mathrm{m}^{2} \\
\text { (INR) }\end{array}$ & 550 & 1184 & 3500 \\
\hline Lifespan & 50 years & 5 years & 25 years \\
\hline
\end{tabular}

Published By: 
On referring to table II, HDPE is found to have better properties in strength to density ratio, cost and lifespan. Hence it can be considered as the best option for float. The float is designed in such a way that the air gets trapped in the structure to give it enough buoyancy to float on water. The HDPE pipes are heated and joined to form a closed square structure as shown in the figure 8. The size is chosen such that it suffices the solar panel considered for floating. The average panel size of a $60 \mathrm{~W}$ panel is $0.6^{*} 0.7 \mathrm{~m}$. Hence the float considered is $1 * 1 \mathrm{~m}$. The simpler the panel the higher the efficiency due to quick cooling rate. The closed structure is then covered with a sheet on both sides where one side provides insulation and the other forms the base on which the panel is placed. The sheets provide extra support and help in trapping air inside so that the withstanding capacity of the float increases.

\section{EXPERIMENT PROTOTYPE}

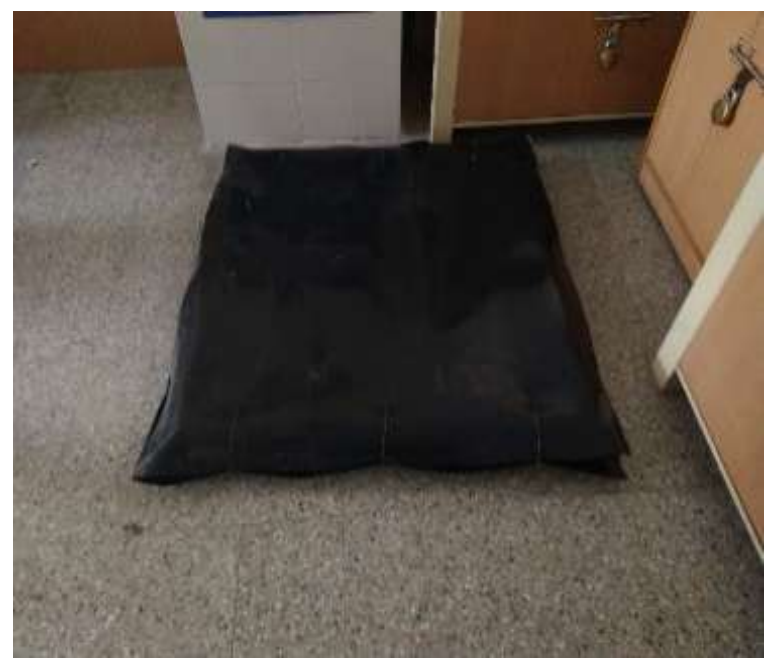

Fig 8. Float structure of HDPE

The ponton designed is made to float on water body essentially a pond. The tilt angle of the solar panel is not a major issue since the experiment is done to compare the efficiency of ground mounted and float solar PV system. Hence the tilt angle is considered as zero degrees for both systems. The experiments were done simultaneously to produce the same conditions between the experiments. The experiment is conducted at peak hours from 11 am to $1: 30$ $\mathrm{pm}$. The rheostat was connected as the load for both experiments. Same type of $60 \mathrm{~W}$ panels was used to ensure precise comparison.

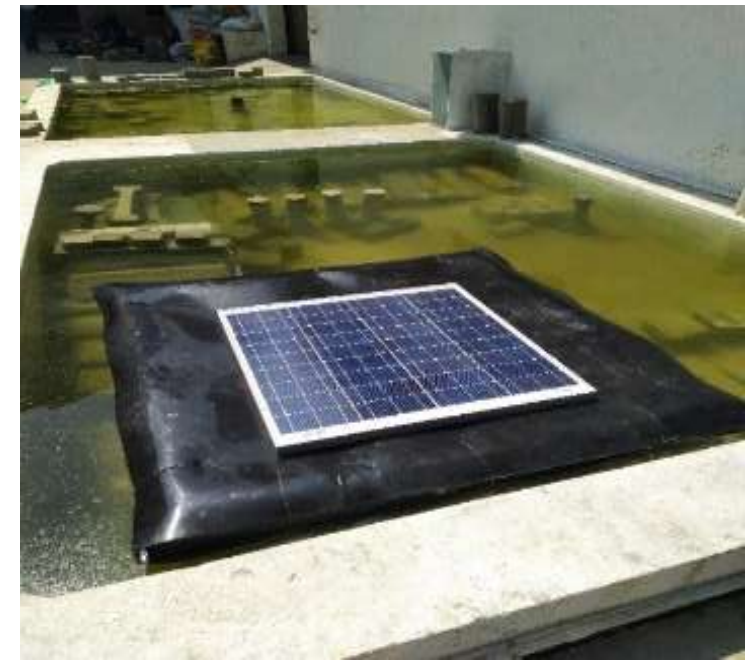

Fig 9. Floating PV panel prototype

\section{RESULTS AND DISCUSSION}

Experimental results were obtained by using multi-meter and temperature of the solar cell is measured using IR thermometer. The overall result shows the increment of power and efficiency of the PV panel when floating on water. The power outputs of both systems are shown in fig 10. For a $50 \mathrm{ohm}$ load the floating panel gives a power of $43.6192 \mathrm{~W}$ whereas the ground mounted gives an output of $39.2 \mathrm{~W}$, which shows that in the same duration the floating panel produces $4.4192 \mathrm{~W}$. The energy gain of a floating solar panel is $11.27 \%$ more than that of ground mounted system. On that particular day the temperature reached as high as $66.1^{0} \mathrm{C}$ for a ground mounted system

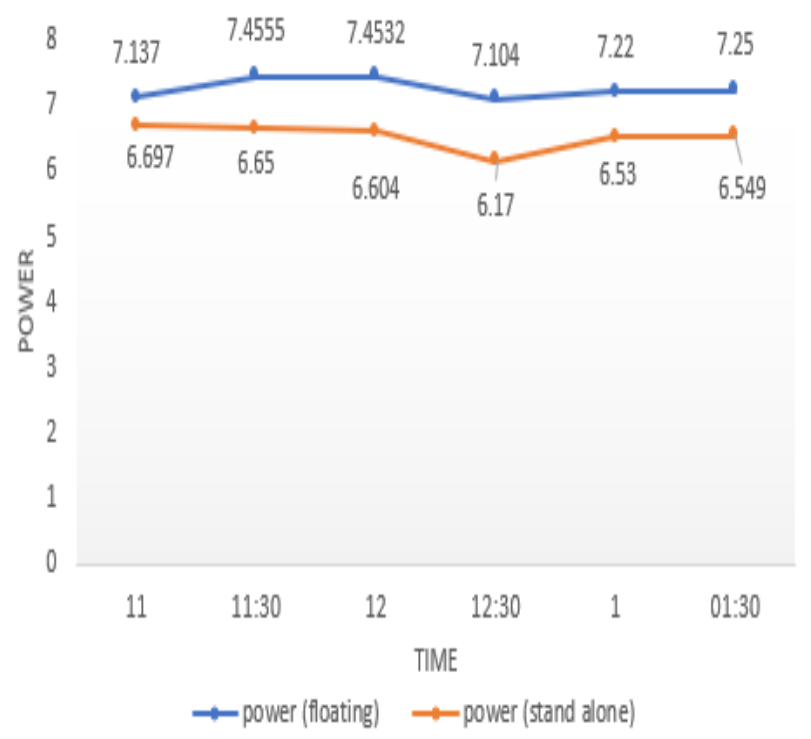

Fig 10. Power output of ground mounted and floating PV system 


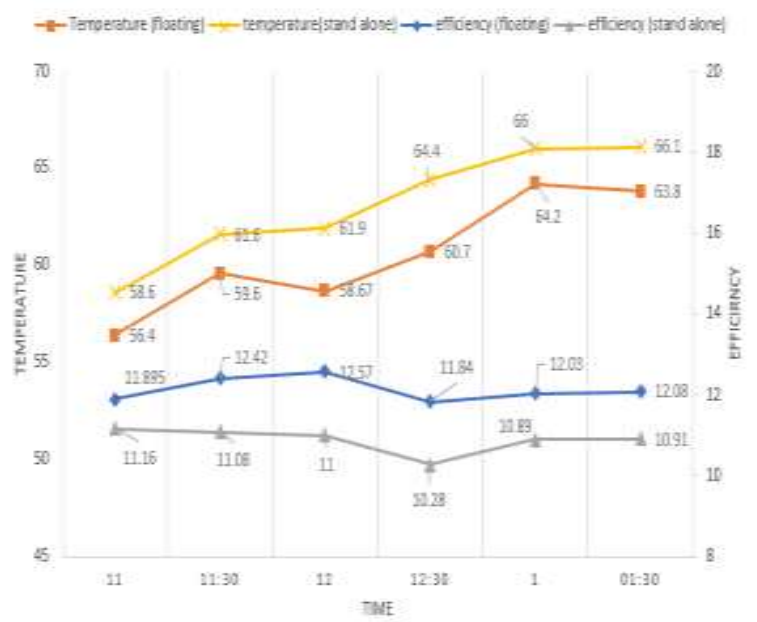

Fig 11. Temperature and efficiency of floating and ground mounted PV system

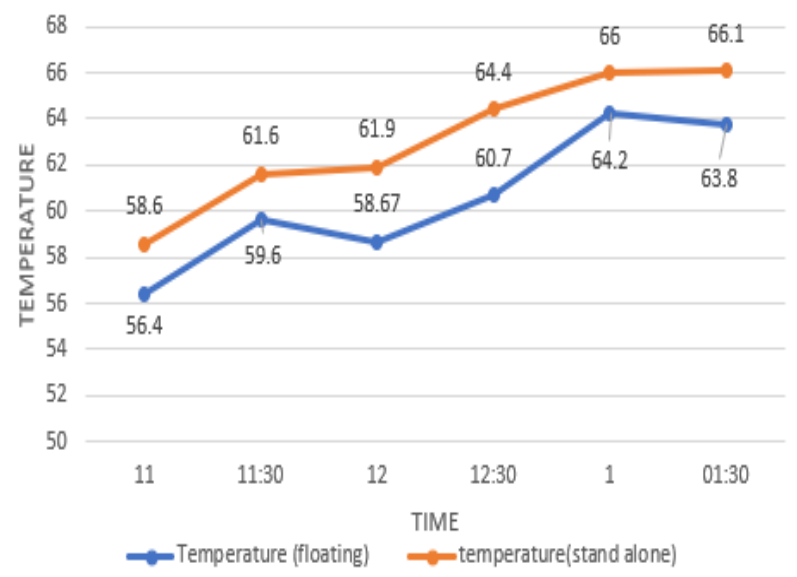

Fig 12. Variation of temperature of solar panels

whereas it reached $64.2^{\circ} \mathrm{C}$ for a floating system. The temperature variations have affected the efficiency of the panel which is shown the figure11.The efficiency for a 50 ohm load has a peak of $12.57 \%$ for a floating system whereas it is only $11.16 \%$ for a ground mounted system. The increasing temperature is shown in the figure 12.

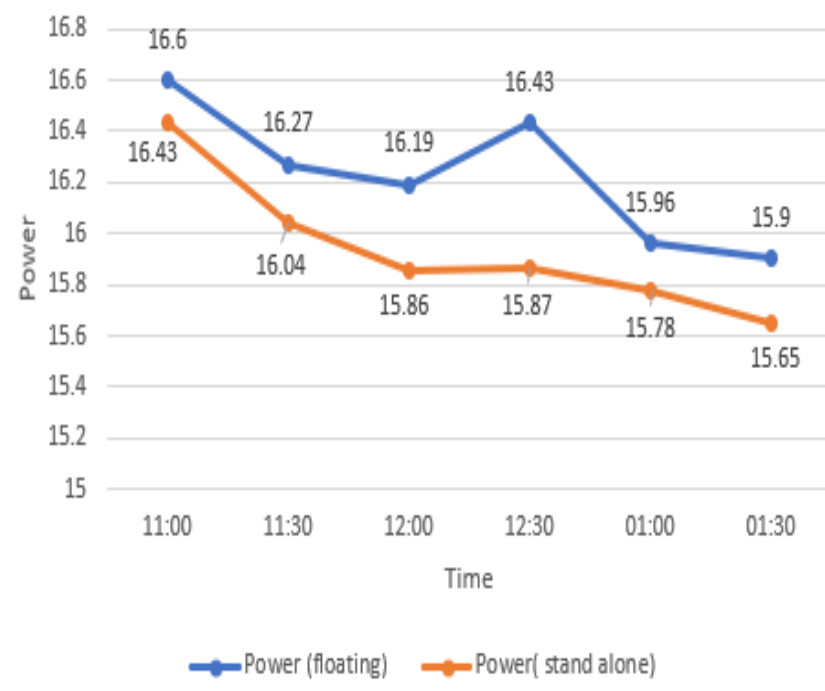

Fig 13. Power output of ground mounted and floating PV system
For a $20 \mathrm{ohm}$ load the efficiency increased to as high as $27.6 \%$ for a floating system whereas it is $27.38 \%$ for a ground mounted system. The power gain is $1.72 \mathrm{~W}$ for a for a floating system which is $1.79 \%$ of a ground mounted system. The respective outputs are shown in the figures 13,14 and 15 .

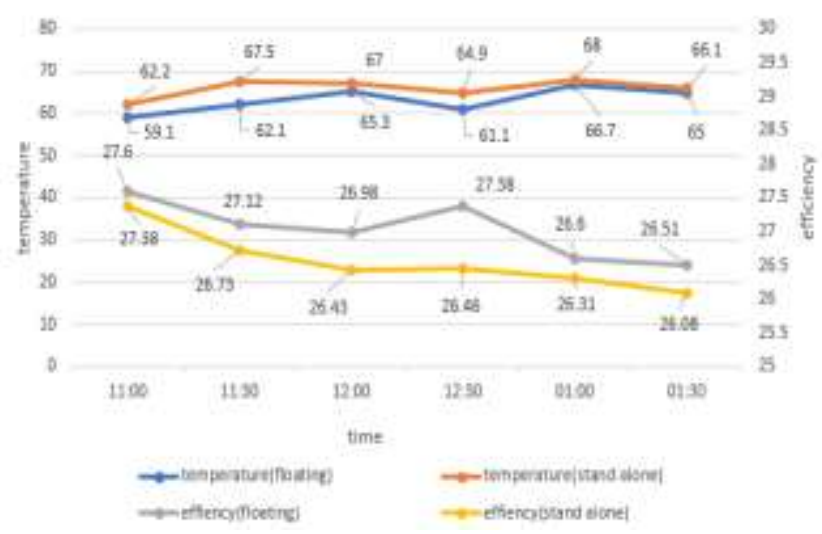

Fig 14. Efficiency and temperatures of both PV systems

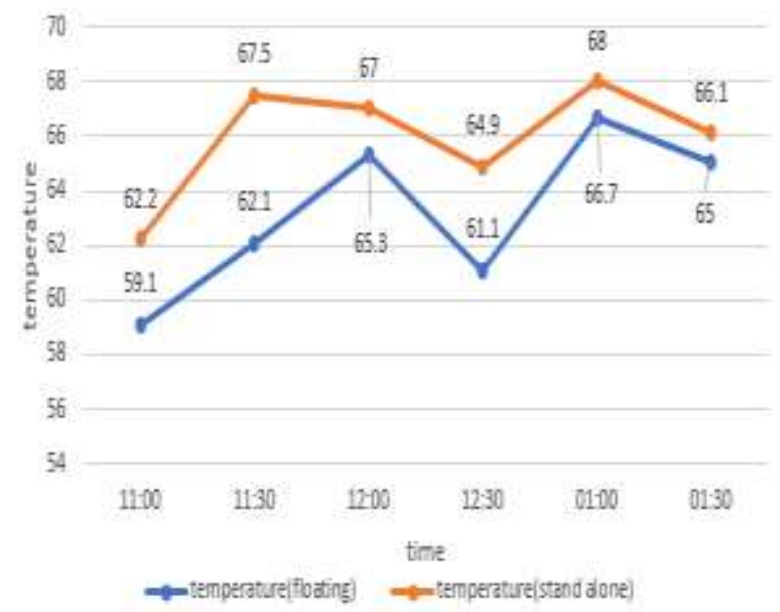

Fig 15. Variation of temperature of standalone and floating PV system

\section{CONCLUSION}

This paper highlights the floating PV system installed on water bodies. Floating system is an innovative step as it could solve land acquisition. The temperature of the panel is kept low and hence it generates more power than those set on land. The power gain is $11 \%$ higher for the floating system and the water evaporation reduced by $70 \%$. The panel can be designed to further increase the efficiency. Different cooling methods can be installed to increase efficiency of the system. Sprinkler system would be feasible idea for the cooling process. Different structures of floats can also be made. One major drawback is it is not advised to be installed on seashores due to the tidal force. This can be overcome by using a different float design. 


\section{REFERENCES}

1. Ming-Tse Kuo, Wen-Yi Lo, "A combination of concentrator photovoltaics and water cooling system to improve solar energy utilization" IEEE Transcations on Industry Applications, vol. 50, no. 4, July/August 2014

2. Patil (Desai) Sujay S., Wagh M. M., Shinde N. N. "A Review on Floating Solar Photovoltaic Power Plants" International Journal of Scientific \& Engineering Research Volume 8, pp. 789-794, June-2017

3. Subhash Kumar, Dr. Tarlochan kaur, "Solar PV performance-issues and challenges", International Journal Of Innovative Research In Electrical, Electronics, Instrumentation And Control Engineering, vol. 2, no. 11, pp.2168-2172 November 2014

4. Bazilian MD, Leenders F, van Der Ree B, Prasad D. "Photovoltaic cogeneration in the built environment" Solar Energy. 2001; 71:57-69

5. Akole Harshal U, Jadhav Pallavi S, "Floating Solar Plant", International Conference for Convergence in Technology, April, 2018

6. Filipa Reis, "Development of photovoltaic systems with concentration", November 2013

7. Sharp C. $80 \mathrm{~W}$ Polycrystalline silicon PV module. NE80E2EA2007

8. Abdolzadeh M, Ameri M. Improving the effectiveness of a photovoltaic water pumping system by spraying water over the front of photovoltaic cells. Renewable Energy. 2009; 34:91-6

9. Tonui J, Tripanagnostopoulos Y. Improved PV/T solar collectors with heat extraction by forced or natural air circulation. Renewable Energy. 2007; 32:623-37

10. Anderson TN, Duke M, Morrison G, Carson JK. Performance of a building integrated photovoltaic/thermal (BIPVT) solar collector. Solar Energy. 2009; 83:445-55 